\title{
The Effect of STEM Education on the Attitudes of Secondary School Students: A Meta-Analysis
}

\author{
Siti Nurul Izzah ${ }^{1}$, Wiyanto ${ }^{2}$ \\ ${ }^{1}$ SMP Negeri 2 Pekalongan, Jl. Cendrawasih 11 Pekalongan, Indonesia \\ ${ }^{1,2}$ Science Education, Graduate School, Universitas Negeri Semarang, Indonesia \\ ${ }^{1}$ Coressponding email: nurulcahaya88@gmail.com
}

\begin{abstract}
The aim of the study is to synthesize empirical research on the influence of STEM (Science, Technology, Engineering, and Mathematics) education on the attitude of middle school students. After screening some articles, research report, and dissertations, there are 15 (fifteen) articles that meet the established requirements. The result of the meta-analysis revealed that there was an influence between STEM education and the positive attitude of middle school students to the STEM fields. Based on the results of the research could be recommended that the need for research looking for relationship between STEM education to the scientific attitude or learners.
\end{abstract}

Keywords: meta-analysis, attitudes, STEM, middle school.

\section{Introduction}

Achieving success in the $21^{\text {st }}$ century learning requires learning and innovation skills that include: (1) critical thinking and problem, (2) communication and collaboration, and (3) creativity and innovation (Baran, Bilici, Mesutoglu, \& Ocak (2016), Firman, (2016)). Furthermore skills that have to be mastered in the $21^{\text {st }}$ century learning is expertise in technology (Ritz and Fan, 2015). Learning using Science, Technology, Engineering, and Mathematics integrated approach can help the success of $21^{\text {st }}$ century learning skills achievement. One of the characteristics of STEM-based education is integrating Science, Technology, Engineering, and Mathematics in problem solving found in real life (J. R. Young, N. Ortiz, and J. L. Young, 2016). The principles of STEM education help to improve creativity and problem solving (Becker \& Park (2011), Ministry of Education and Culture (2014)). The previous research findings reveal that STEM education affects academic success, creative thinking skills, scientific attitudes, and science process skills (Becker \& Park (2011), Ministry of Education and Culture (2014)). Meta-analysis that reveal the influence of STEM education on academic achievement, creativity, and science process skills has been done (Becker \& Park (2011), Larson \& Miller, (2011), M. S. Corlu, R. M. Capraro, \& M. M. Capraro, (2014)). Furthermore, it is necessary to reveal any scientific attitude influenced by STEM education.
STEM education is implemented in various countries for various reasons, namely the development of science increases, the development of global economy, the needs of individual education need to be well prepared, the need for innovation in all fields (Becker \& Park (2011), Ministry of Education and Culture (2014)). Another reason is the achievement of students in the fields of STEM subject is decline. It can be correlated with the low achievement of international studies of Trends in International Mathematics and Science Study (TIMMS) and the Program for International Student Assessment (PISA) (Greenberg, Weissberg, O'Brien, Zins, Fredericks, Resnik, \& Elias (2003). The achievements of Indonesian learners aged 15 years (grade 8) on International studies in Science are at level 2. Students have sufficient scientific knowledge to provide possible explanations in a known context or draw conclusions based on simple inquiry. Students are able to do direct reasoning and make literal interpretations of the results of scientific inquiry or problem solving technology (Kier, Blanchard, Osborne \& Albert (2013). The achievement of Indonesian students in International studies is still low as stated that the quality of science education in Indonesia is still low when compared with other developing countries (OECD, 2014). The low quality of science education is indicated by the low achievement of science literacy in international studies. The results of previous research reveal that there is a strong relationship between the principles of STEM education with 
international study achievement (Becker \& Park (2011). Further stated by Becker \& Park (2011) that STEM education is one of the way to achieve success in international studies such as TIMMS and PISA, so STEM education in Indonesia needs to be developed.

The characteristics of STEM education are highly relevant and compatible with the 2013 curriculum. As stated in the 2013 curriculum document that one of the improvements of the mind-set developed by the 2013 curriculum is the strengthening of multi-disciplinary learning patterns and the strengthening of critical learning patterns (Rusilowati, Kurniawati, Nugroho \& Widiyatmoko (2016). Some researchers believe that STEM education encompasses a broader understanding of knowledge, skills and attitudes drawn up in collaborative ways (Duschl \& Bybee (2014). This is in line with the 2013 curriculum framework in Indonesia that develops the attitudes, knowledge, and skills of learners.

Efforts to increase students' interest in both STEM and STEM careers are increasing internationally. Educational institutions recommend that the effort to attract learners in the field STEM and STEM careers starting from High School (Bybee \& Mccrae (2011). STEM education provides an opportunity for teachers to show learners how STEM's concepts, principles and techniques are used in an integrated way in the development of products, processes, and systems used in their daily lives (J. R. Young, N. Ortiz, and J. L. Young. (2016). Therefore a meta-analysis of the influence of STEM education on scientific attitudes or positive attitudes of high school students in STEM field is needed.

\section{Methods}

This study aims at concluding the outline of an empirical study of the effect of STEM education on the attitudes of high school students. This study is a meta-analysis study.

\subsection{Problem definitions}

The research questions will be answered as follows:

(1) Is there any influence between STEM education and the attitude of learners towards STEM field?

(2) Is there any influence between STEM education and students' attitude toward $\mathrm{S}$ (Science) field?
(3) Is there any influence between STEM education and student's attitude toward T (Technology) field?

(4) Is there any influence between STEM education and students' attitude toward $\mathrm{E}$ (engineering) field?

(5) Is there an influence between STEM education and the attitude of learners towards the field of M (Mathematics)?

(6) Is there any influence between STEM education and the scholarly attitude of learners?

\subsection{Steps of the research}

This research starts by screening several articles, research reports and dissertations that can be accessed from the database. The database used to do the screening as follows: Google Scholar, ERIC (Educational Resources Information Centre), and link.springer. The criteria that an article entered in the material of meta-analysis, as follow:

(1) The research is published between 2009 and 2017 or for the last 10 (ten) years

(2) The articles can be accessed by Keywords: STEM, STEM Education, STEM Learning, Attitudes, Scientific Attitudes, and Middle School

(3) The article examines the effect of STEM education on the attitude of learners in the field of STEM

Of the 34 articles, 15 (fifteen) articles are specified in accordance with the study materials that have been determined. Table 2 . Indicates the coding method in performing the meta-analysis.

Further research data to be conducted metaanalysis is in table 2 . Then the data is analysed by using 7 stages as stated in table 1 .

Table 1. The Step of Data Analysis

\begin{tabular}{cl}
\hline Steps & \multicolumn{1}{c}{ Activity } \\
\hline 1 & Determining the topic to be researched \\
2 & screening of the literature \\
3 & Reading the data collected \\
4 & Determine whether the data obtained is \\
& related to the topic \\
5 & Performing data conversion \\
6 & Doing an abstraction \\
7 & Creating synthesis \\
\hline
\end{tabular}


Table 2. Coding Meta-analysis data

\begin{tabular}{|c|c|c|c|c|}
\hline Code & Theme & Statement & $\begin{array}{l}\text { Fre } \\
\text { que } \\
\text { ncy }\end{array}$ & $\begin{array}{l}\text { Perce } \\
\text { ntage }\end{array}$ \\
\hline \multirow[t]{2}{*}{$\begin{array}{l}\text { A- } \\
\text { STE } \\
\text { M }\end{array}$} & $\begin{array}{l}\text { Influence of } \\
\text { STEM } \\
\text { Education on } \\
\text { Attitudes in } \\
\text { STEM field }\end{array}$ & $\begin{array}{l}\text { STEM education has } \\
\text { no effect on Attitudes } \\
\text { in STEM field }\end{array}$ & 1 & 6.67 \\
\hline & & $\begin{array}{l}\text { STEM education } \\
\text { influences Attitudes } \\
\text { in the STEM field }\end{array}$ & 6 & 40 \\
\hline \multirow[t]{2}{*}{ A-S } & $\begin{array}{l}\text { Influence of } \\
\text { STEM } \\
\text { Education on } \\
\text { Attitudes in S } \\
\text { (Science) }\end{array}$ & $\begin{array}{l}\text { STEM Education has } \\
\text { no effect on Attitudes } \\
\text { on Science }\end{array}$ & 0 & 0 \\
\hline & & $\begin{array}{l}\text { STEM education has } \\
\text { an effect on Attitudes } \\
\text { in science }\end{array}$ & 6 & 40 \\
\hline \multirow[t]{2}{*}{ A-T } & $\begin{array}{l}\text { Effect of STEM } \\
\text { Education on } \\
\text { Attitudes on T } \\
\text { (Technology) }\end{array}$ & $\begin{array}{l}\text { STEM Education has } \\
\text { no effect on Attitudes } \\
\text { in Technology field }\end{array}$ & 0 & 0 \\
\hline & & $\begin{array}{l}\text { STEM Education has } \\
\text { an effect on Attitudes } \\
\text { in Technology field }\end{array}$ & 2 & 13.33 \\
\hline \multirow[t]{2}{*}{ A-E } & $\begin{array}{l}\text { Influence of } \\
\text { STEM } \\
\text { Education on } \\
\text { Attitudes in E } \\
\text { (Engineering) }\end{array}$ & $\begin{array}{l}\text { STEM education has } \\
\text { no effect on Attitudes } \\
\text { in Engineering }\end{array}$ & 0 & 0 \\
\hline & & $\begin{array}{l}\text { STEM Education has } \\
\text { an effect on Attitudes } \\
\text { in Engineering }\end{array}$ & 1 & 6.67 \\
\hline \multirow[t]{2}{*}{ A-M } & $\begin{array}{l}\text { Influence of } \\
\text { STEM } \\
\text { Education on } \\
\text { Attitudes in M } \\
\text { (Mathematics) }\end{array}$ & $\begin{array}{l}\text { STEM education has } \\
\text { no effect on Attitudes } \\
\text { in Mathematics field }\end{array}$ & 0 & 0 \\
\hline & & $\begin{array}{l}\text { STEM Education has } \\
\text { an effect on Attitudes } \\
\text { in Mathematics field }\end{array}$ & 0 & 0 \\
\hline \multirow[t]{2}{*}{$\begin{array}{l}\text { A- } \\
\text { SA }\end{array}$} & $\begin{array}{l}\text { Effect of STEM } \\
\text { Education on } \\
\text { Scientific } \\
\text { Attitudes }\end{array}$ & $\begin{array}{l}\text { STEM education has } \\
\text { no effect on Attitudes } \\
\text { on Scientific } \\
\text { Attitudes }\end{array}$ & 0 & 0 \\
\hline & & $\begin{array}{l}\text { STEM education } \\
\text { influences Attitudes } \\
\text { on Scientific } \\
\text { Attitudes }\end{array}$ & 3 & 20 \\
\hline
\end{tabular}

\section{Result and Discussions}

Research data related to the influence of STEM education on the positive attitude of learners toward STEM field is not found in research journal in Indonesia. So all the data analysed is the result of research from abroad. The research findings related to the type of research used are presented in Table 3.

Table 3. Types of Research Used

\begin{tabular}{llc}
\hline Research methods & Total & Percentage \\
\hline Quantitative & 10 & 66.67 \\
Qualitative & 1 & 6.67 \\
Mixed-Methods & 3 & 20.00 \\
Action Research & 1 & 6.67 \\
Total & $\mathbf{1 5}$ & $\mathbf{1 0 0}$ \\
\hline
\end{tabular}

Based on table 3 it can be seen that research method is the most widely used in expressing the influence of STEM education on positive attitude toward STEM field that is quantitative

method. The findings based on the results of the research already given the code are stated in table 4.

Table 4. Coding Meta-analysis data

\begin{tabular}{|c|c|c|}
\hline No & Theme & Type and Category of Data \\
\hline 1 & A-STEM & $\begin{array}{l}\text { Influence of STEM Education on } \\
\text { Attitudes in STEM field }\end{array}$ \\
\hline 2 & A-S & $\begin{array}{l}\text { Influence of STEM Education on } \\
\text { Attitudes in S (Science) }\end{array}$ \\
\hline 3 & A-T & $\begin{array}{l}\text { Effect of STEM Education on } \\
\text { Attitudes on } \mathrm{T} \text { (Technology) }\end{array}$ \\
\hline 4 & A-E & $\begin{array}{l}\text { Influence of STEM Education on } \\
\text { Attitudes in E (Engineering) }\end{array}$ \\
\hline 5 & A-M & $\begin{array}{l}\text { Influence of STEM Education on } \\
\text { Attitudes in M (Mathematics) }\end{array}$ \\
\hline 6 & A-SA & $\begin{array}{l}\text { Effect of STEM Education on } \\
\text { Scientific Attitudes }\end{array}$ \\
\hline
\end{tabular}

Table 4 shows that almost all studies reveal an influence between STEM education on positive attitudes of learners towards the STEM field, either partially or partially. There is only 1 study which revealed no influence between STEM education and positive attitude toward STEM field. The research data related to the field of Mathematics is partially not found.

Results of research on the influence of STEM education on scientific attitudes there is only one study that is revealing about beliefs. There needs to be further research that reveals the influence of STEM education on other components of scientific attitudes. The attitude dimension to the IPA in accordance with PISA is given in Table 5 below.

Table 5. Attitude Dimension on Science

Dimensions Indicator

Interest in

Science

Support for

Scientific

Discovery

Have a sense of responsibility towards natural resources and environment
- Showing curiosity about science and current issues related to science.

- Demonstrating the desire to seek information related to science and career in science

- Understanding differences in points of view and opinions

- Supporting the use of factual information and rational explanations

- Stating the need to think logically and pay attention to the process of drawing conclusions.

- Demonstrating a sense of responsibility for maintaining environmental sustainability

- Demonstrating personal environmental awareness

- Demonstrating the desire to take concrete steps to preserve natural resources 


\section{Conclusion}

This study has conducted a metaanalysis based on the data needed to be used as a guide in subsequent research. The results of the meta-analysis revealed that there is an effect of STEM education on the positive attitude of high school students in the STEM field.

\section{References}

A. Lukum. (2015). "Evaluasi Program Pembelajaran IPA SMP Menggunakan Model Countenance Stake," J. Penelit. dan Eval. Pendidik., vol. 19, no. 1, pp. 25-37.

A. Rusilowati, L. Kurniawati, S. E. Nugroho, and A. Widiyatmoko. (2016). "Developing an instrument of scientific literacy asessment on the cycle theme," Int. J. Environ. Sci. Educ., vol. 11, no. 12, pp. $5718-5727$.

B. Trilling and C. Fadel. (2012). "21st Century Skills: Learning for Life in Our Times," pp. 1-243.

B. Yildirim. (2016). "An Analyses and MetaSynthesis of Research on STEM Education," J. Educ. Pract., vol. 7, no. 34, pp. 23-33

E. Baran, S. C. Bilici, C. Mesutoglu, and C. Ocak. (2016). "Moving STEM Beyond Schools : Students ' Perceptions about an Out-of- School STEM Education Program," Int. J. Educ. Math. Sci. Technol., vol. 4, no. 1, pp. 9-19.

H. Firman. (2016). "STEM education as framework for chemical education innovation to strengthen the national competitiveness in the era of ASEAN economic community," in Prosiding Seminar Nasional Kimia dan Pembelajarannya, no. September.

J. M. Ritz and S.-C. Fan. (2015). "STEM and technology education: international state-of-the-art," Int. J. Technol. Des. Educ., vol. 25, no. 4, pp. 429-451.

J. R. Young, N. Ortiz, and J. L. Young. (2016) "STEMulating Interest: A MetaAnalysis of the Effects of Out-ofSchool Time on Student STEM Interest," Int. J. Educ. Math. Sci. Technol., vol. 5, no. 1, p. 62.

K. Becker and K. Park. (2011). "Effects of integrative approaches among science, technology , engineering , and mathematics ( STEM ) subjects on students ' learning: A preliminary meta-analysis," J. STEM Educ., vol. 12, no. 5, pp. 23-38.

Ministry of Education and Culture. (2014). Lampiran I. Peraturan Menteri Pendidikan dan Kebudayaan Nomor 58 Tahun 2014 Tentang Kerangka Dasar dan Struktur Kurikulum Sekolah Menengah Pertama/Madrasah Tsanawiyah. pp. 1-8.

Ministry of Education and Culture. (2014). Peraturan Menteri Pendidikan dan Kebudayaan Nomor 58 Tahun 2014 tentang Kurikulum 2013 Sekolah Menengah Pertama/Madrasah Tsanawiyah.

L. C. Larson and T. N. Miller. (2011). "21st Century Skills: Prepare Students for the Future," Kappa Delta Pi Rec., vol. 47, no. 3, pp. 121-123.

M. S. Corlu, R. M. Capraro, and M. M. Capraro. (2014). "Introducing STEM education: Implications for educating our teachers for the age of innovation," Educ. Sci., vol. 39, no. 171, pp. 74-85.

M. T. Greenberg, R. P. Weissberg, M. U. O’Brien, J. E. Zins, L. Fredericks, H. Resnik, and M. J. Elias. (2003). "Enhancing school-based prevention and youth development through coordinated social, emotional, and academic learning.," Am. Psychol., vol. 58 , no. 6-7, pp. 466-474.

M. W. Kier, M. R. Blanchard, J. W. Osborne, and J. L. Albert. (2013). "The Development of the STEM Career Interest Survey (STEM-CIS)," Res. Sci. Educ

OECD. (2014). PISA 2012 results: What students know and can do-Student Performance in Mathematics, Reading and Science, vol. I, no. Volume I.

R. A. Duschl and R. W. Bybee. (2014). "Planning and carrying out investigations: an entry to learning and to teacher professional development around NGSS science and engineering practices," Int. J. STEM Educ., vol. 1, no. 1, p. 12.

R. Bybee and B. Mccrae. (2011). "Scientific Literacy and Student Attitudes: Perspectives from PISA 2006 science Scientific Literacy and Student Attitudes: Perspectives from PISA 
2006 science," Int. J. Sci. Educ., vol. 331 , no. 1 , pp. 7-26

W. Wiyanto. (2007). "Supervisi Pendidikan IPA Bercirikan Dialog Profesional
Kesejawatan dalam Konteks Pelaksanaan MBS," Lembaran Ilmu Kependidikan, vol. 36, no. 1, pp. 7483. 